\title{
O PAPEL DO VÍRUS EPSTEIN-BARR NA TUMORIGÊNESE HUMANA
}

\author{
THE ROLE OF EPSTEIN-BARR VIRUS IN HUMAN TUMORIGENESIS
}

Alfredo Ribeiro-Silva ${ }^{1} \&$ Sérgio Zucoloto

\begin{abstract}
${ }^{1}$ Médico Assistente. Serviço de Patologia. Hospital das Clínicas de Ribeirão Preto (HCFMRP/USP). ${ }^{2}$ Docente. Departamento de Patologia. Faculdade de Medicina de Ribeirão Preto - USP.

Correspondência: Alfredo Ribeiro-Silva. Serviço de Patologia. Hospital das Clínicas de Ribeirão Preto. Av. Bandeirantes, 3900Campus Universitário - USP. CEP 14048-900 Ribeirão Preto - SP, Brasil. E-mail: ardsilva@rpa.fmrp.usp.br. FAX: 0xx(16)6330095. Fone: $0 \times x(16) 6023240$
\end{abstract}

RIBEIRO-SILVA A \& ZUCOLOTO S. O papel do vírus Epstein-Barr na tumorigênese humana. Medicina, Ribeirão Preto, 36: 16-23, jan./mar. 2003.

RESUMO: O vírus Epstein Barr, também conhecido pela denominação inglesa, Epstein-Barr virus ou simplesmente EBV, é um vírus da família Herpes, que causa a mononucleose infecciosa, em humanos. Existe forte correlação entre a infecção latente pelo EBV e o desenvolvimento de diversos tumores malignos, como o linfoma de Burkitt, a doença de Hodgkin, o linfoma $B$ e o carcinoma nasofaríngeo. Há, também, evidências de que o EBV possa estar associado a outras neoplasias malignas, principalmente a carcinomas gástricos, carcinomas mamários, leiomiossarcomas, linfomas T e carcinomas linfoepitelioma-like de glândulas salivares, pulmão e timo. Várias das proteínas expressas pelo EBV atuam diretamente, como oncogene, estimulando a proliferação das células infectadas. Além disso, o DNA viral, ao integrar-se ao genoma do hospedeiro, pode causar mutações em genes reguladores do ciclo celular, sobretudo no gene supressor, tumoral, p53, favorecendo o aparecimento de células neoplásicas.

UNITERMOS: Infecção. Herpesvirus 4 Humano. Neoplasias.

\section{1- INTRODUÇÃO}

O vírus Epstein-Barr, mais conhecido pela denominação inglesa, Epstein-Barr Vírus (EBV), foi descoberto, em 1964, por um estudo de microscopia eletrônica, de cultura de células obtidas de linfoma de Burkitt $^{(1)}$. Quatro anos após, em 1968, demonstrou-se que o EBV era o agente etiológico da mononucleose infecciosa $^{(2)}$.

O vírus Epstein-Barr é um membro da família Herpes. O genoma viral encontra-se dentro de um nucleocapsídeo, que, por sua vez, é envolto pelo envelope viral. O genoma do EBV consiste de uma molécula de DNA linear, de 172 quilobases, que codifica, aproximadamente, 100 proteínas virais. Durante a replicação viral, essas proteínas são importantes para a regulação da expressão dos genes virais, para a replicação do DNA viral, para formar a estrutura de componentes estruturais do vírion e para modular a resposta imune do hospedeiro ${ }^{(3)}$.

O EBV infecta mais de $90 \%$ da população mundial $^{(4)}$. A taxa de endemicidade para o vírus EpsteinBarr varia conforme a região geográfica, sendo extremamente elevada no Norte da África (Algéria e Tunísia) e extremamente baixa no Norte da Europa (Dinamarca e Holanda). O Brasil é considerado um país de endemicidade intermediária entre aquelas duas regiões ${ }^{(4)}$. A infecção ocorre, geralmente, na infância e é assintomática na maioria dos casos, persistindo de forma latente durante toda a vida do indivíduo. Nos 
países industrializados, a infecção primária, muitas vezes, ocorre na adolescência ou mesmo na fase adulta, causando uma doença linfoproliferativa, denominada mononucleose infecciosa ${ }^{(5)}$. Mais de 50\% dos pacientes com mononucleose infecciosa apresentam febre, linfadenopatia e faringite. Menos de 10\% apresentam esplenomegalia, petéquias no palato e hepatomegalia. Normalmente, a doença é autolimitada. Raramente, prolonga-se por mais de seis meses, quando passa a ser denominada infecção crônica, ativa, pelo $\mathrm{EBV}^{(5)}$.

A infecção de humanos pelo EBV, usualmente, ocorre pelo contato com secreções orais. $\mathrm{O}$ vírus se replica nas células da orofaringe e, praticamente em todos os pacientes que apresentam sorologia positiva, pode-se detectar o vírus na saliva ${ }^{(6)}$.

\section{2- INFECÇÃO LATENTE PELO VÍRUS EPSTEIN-BARR}

Os estudos iniciais sugeriam que o vírus se replicava nas células epiteliais da orofaringe, para, posteriormente, infectarem as células $\mathrm{B}^{(7)}$. Estudos posteriores comprovaram que, na realidade, as células B da orofaringe, e não as células epiteliais, representam o sítio primário da infecção ${ }^{(8)}$. A infecção de células epiteliais pelo EBV in vitro resulta em replicação ativa e lise da célula infectada. Por outro lado, infecção in vitro do $\mathrm{EBV}$, em células $\mathrm{B}$, resulta em infecção latente com imortalização das células infectadas ${ }^{(9)}$.

Para o vírus entrar na célula B, o envelope glicoprotéico gp350 liga-se ao receptor viral (molécula CD21) na superfície da célula B. Além disso, moléculas da classe II do complexo maior de histocompatibilidade (MHC) servem como cofator para a infecção das células $\mathrm{B}^{(10)}$. Pacientes com agamaglobulinemia ligada ao X não possuem células B maduras, não sendo infectados pelo vírus nem in vitro nem in vivo ${ }^{(11)}$.

Acredita-se que os locais de persistência do EBV, no indivíduo, sejam as células $\mathrm{B}$, latentes de memória. Em adultos normais, de 01 a 50 células $B$ por milhão estão infectadas pelo EBV e, em cada indivíduo, o número de células infectadas latentes permanece estável por anos ${ }^{(12)}$.

Cerca de 100 genes virais são expressos durante a replicação, mas apenas 10 são expressos in vitro nas células $\mathrm{B}$, infectadas, latentes: seis proteínas nucleares (EBNAs), duas proteínas de membrana (LMPs) e dois tipos de RNA não transladado (EBERs). Essa diminuição no número de proteínas virais limita o reconhecimento das células infectadas pelas células $\mathrm{T}$, citotóxicas ${ }^{(13)}$.
A proteína do antígeno nuclear 1 do EBV (EBNA1) liga-se ao DNA viral, fazendo com que o genoma viral permaneça na célula infectada como um episomo circular ${ }^{(14)}$. Desempenha, portanto, um papel central na manutenção da infecção latente pelo EBV. O EBNA 1 é necessário para a replicação do genoma viral e é um fator regulador chave, na transcrição dos genes latentes, de infecção ${ }^{(15)}$. A proteína transcrita do EBNA1 é separada em um domínio N-terminal em um domínio C-terminal, por uma seqüência repetitiva de glicina, glicina e alanina. Essa seqüência inibe a apresentação do antígeno ao complexo maior de histocompatibilidade, inibindo a resposta imune do hospedeiro ao EBV. Além disso, essa sequiência aumenta a meia-vida do EBNA1 ${ }^{(16)}$. A expressão do EBNA-1, em carcinomas, correlaciona-se com um pior prognóstico $^{(17)}$.

$\mathrm{O}$ antígeno nuclear 2 do EBV (EBNA2) aumenta a expressão das proteínas de membrana latente 1 e 2 (LMP1 e LMP2), assim como das proteínas celulares que contribuem para o crescimento das células $\mathrm{B}^{(18)}$. Existem 3 subunidades do EBNA3: EBNA3a, EBNA3b e EBNA3c ${ }^{(3)}$. O antígeno nuclear 3 do EBV (EBNA3) também regula a expressão de genes celulares, aumentando a habilidade do EBNA2 em regular o LMP1 ${ }^{(19)}$.

O LMP2 previne a reativação do EBV latente nas células infectadas, através do bloqueio da fosforilação da quinase de tirosina ${ }^{(20)}$. A expressão do LMP2, em camundongos transgênicos, faz com que células $B$ não transformadas sobrevivam mesmo na ausência da sinalização normal para receptores de células $\mathrm{B}^{(21)}$.

Através da análise gênica é possível distinguir os tipos $\mathrm{A}$ e $\mathrm{B}$ do $\mathrm{EBV}$, porque as seqüências dos genes EBNA-2, EBNA-3a, EBNA-3b e EBNA-3c são diferentes entre si ${ }^{(22)}$. O tipo A do EBV é muito mais eficiente em imortalizar as células B dos linfomas do que o tipo $\mathrm{B}^{(23)}$, mas acredita-se que o tipo $\mathrm{B}$ só é capaz de transformar células $B$, em indivíduos imunodeficientes ${ }^{(24)}$. No Brasil e nos países ocidentais, o tipo A é o prevalente, enquanto, na África Equatorial, o tipo B é o mais frequientemente detectado ${ }^{(25)}$.

\section{3- ASSOCIAÇÃO ENTRE O VÍRUS EPSTEIN- BARR E NEOPLASIAS}

Em 1970, O DNA do vírus Epstein-Barr foi detectado em tecidos de pacientes com carcinoma nasofaríngeo ${ }^{(26)}$. Na década de 1980 , o EBV foi associado ao linfoma não Hodgkin e à leucemia de células pilosas, em pacientes com a síndrome da imunode- 
ficiência adquirida (AIDS) ${ }^{(27,28)}$. Desde então, o EBV tem sido identificado em vários tumores, incluindo as síndromes linfoproliferativas de células B, o linfoma de células T e a doença de Hodgkin ${ }^{(29,30)}$. Em 1997, o EBV foi classificado pela International Agency for Research on Cancer, como um carcinógeno de grau I. Carcinógenos de grau I são todos os agentes que, comprovadamente, causam neoplasias em humanos ${ }^{(31)}$.

Também existem evidências de que o EBV possa estar associado a outros tumores malignos, como o carcinoma gástrico, o carcinoma mamário, o leiomiossarcoma, em pessoas imunodeprimidas, e o carcinoma linfoepitelioma-like de glândulas salivares, pulmão, timo, trato hepatobiliar e esôfago ${ }^{(32 / 38)}$. O papel do EBV, na etiopatogênese dessas neoplasias, particularmente em relação ao carcinoma mamário e hepatocelular, necessita ser mais bem investigado ${ }^{(39)}$.

O carcinoma linfoepitelioma-like do pulmão está fortemente associado à infecção pelo EBV, em pacientes asiáticos; entretanto, a mesma associação não foi verificada em ocidentais, sugerindo que possam existir diferenças étnicas na susceptibilidade ao desenvolvimento de neoplasias pelo $\mathrm{EBV}^{(40)}$. De fato, um estudo, envolvendo várias etnias residindo em um mesmo local na Malásia, evidenciou diferenças importantes na incidência de linfoma não Hodgkin, associado ao $\mathrm{EBV}^{(41)}$. Além disso, a expressão do EBV, em carcinomas gástricos, é semelhante em japoneses que residem no Japão e em japoneses que residem no Brasil $^{(42)}$. Esses dados sugerem que a susceptibilidade genética ao EBV seja mais importante do que as diferenças geográficas.

A detecção dos marcadores de infecção latente varia de doença para doença, seguindo 4 tipos de expressão, conforme especificado na Tabela I ${ }^{(13)}$. A porcentagem de casos positivos para o EBV, em cada uma das doenças que já foram associadas a esse vírus, varia enormemente, conforme atesta a Tabela II ${ }^{(43)}$.

\section{4- MECANISMOS DE TUMORIGÊNESE}

As células com infecção latente podem perder o controle de proliferação por mecanismos ainda pouco conhecidos, provavelmente relacionados a disfunções do sistema imunológico ${ }^{(44)}$. Sabe-se que o gene BZLF1 do EBV desempenha um papel chave nesse processo $^{(45)}$.

Existem evidências de que o EBNA1 possa atuar diretamente, como um oncogene ${ }^{(46)}$. A expressão do EBNA-1 pode ser detectada em amostras de tecido parafinado através do método imunoistoquímico (Figura 1A). Virtualmente, o EBNA1 é expresso em todos tecidos neoplásicos, associados ao EBV, mas o nível de expressão varia grandemente entre os tumores $^{(47)}$. O EBNA2 induz a ativação do ciclo replicativo do EBV e sua expressão é essencial para a transformação neoplásica, de linfócitos $\mathrm{B}^{(48)}$. O EBNA3c é essencial para a transformação neoplásica de linfócitos $\mathrm{B}$, porque regula a transcrição de genes envolvidos no processo de imortalização dessas células, como o RBPJkappa e HDAC1. Além disso, o EBNA3c interfere no ciclo da ciclina/cdk-Rb-E2F, que, normalmente, regula a progressão do ciclo celular, estacionando a célula na fase $\mathrm{G} 1^{(49)}$. Recentemente, verificou-se que o EBNA3c inibe, especificamente, a proteína supressora de metástases $\mathrm{Nm} 23$, favorecendo a progressão maligna, com metástases das neoplasias associadas ao $\mathrm{EBV}^{(50)}$. A inibição do $\mathrm{Nm} 23$ é mais acentuada

\section{Tabela I: Tipos de expressão dos genes latentes, do vírus Epstein-Barr

\begin{tabular}{|r|c|c|c|c|c|l|l|}
\hline Latência & EBNA1 & EBNA2 & EBNA3 & LMP1 & LMP2 & EBER & Doença \\
\hline Tipo 1 & + & - & - & - & - & + - & $\begin{array}{l}\text { Linfoma de Burkitt. } \\
\text { Carcinoma mamário. }\end{array}$ \\
\hline Tipo 2 & + & - & - & + & + & + & $\begin{array}{l}\text { Carcinoma de nasofaringe. } \\
\text { Doença de Hodgkin . Linfoma T. }\end{array}$ \\
\hline Tipo 3 & + & + & + & + & + & + & $\begin{array}{l}\text { Doenças linfoproliferativas } \\
\text {.Mononucleose infecciosa. }\end{array}$ \\
\hline Tipo 4 & - & - & - & + & + & + & Portador saudável. \\
\hline
\end{tabular}

Legenda: EBNA, antígeno nuclear do vírus Epstein-Barr; LMP, proteína latente de membrana; EBER RNA, codificado do vírus Epstein-Barr. + expressa o gene, - não expressa o gene, +/- pode ou não expressar o gene. 
Tabela II Porcentagem de casos positivos para o Epstein-Barr em patologias associadas a esse vírus

$$
\text { Doença }
$$

\section{Porcentagem}

\section{Patologias benignas}

Mononucleose infecciosa

Leucoplaquia pilosa, oral

Pseudotumor inflamatório

Linfomas não Hodgkin e neoplasias associadas a imunodeficiências

Linfoma não Hodgkin (todos os subtipos)

Linfoma não Hodgkin, relacionado a AIDS

Linfoma cerebral (relacionado a AIDS)

Linfoma cerebral (pacientes imunocompetentes)

Desordem linfoproliferativa pós-transplante

Linfoma de Burkitt (África)

Linfoma de Burkitt (América do Norte)

Linfoma de Burkitt (relacionado a AIDS)

Linfoma (imunodeficiência primária)

Granulomatose linfomatóide

Linfoma $\mathrm{T}$ periférico

Linfoma T/NK nasal

Tumor de músculo liso, relacionado a AIDS

\section{Doença de Hodgkin}

Doença de Hodgkin (todos os subtipos)

Doença de Hodgkin (celularidade mista)

Doença de Hodgkin (esclerose nodular)

Doença de Hodgkin (predominância linfocitária)

Doença de Hodgkin (depleção linfocitária)

Doença de Hodgkin (relacionada a AIDS)

\section{Carcinomas}

Carcinoma de nasofaringe (Ásia)

Carcinoma de nasofaringe (América do Norte)

Linfoepitelioma-like

Adenocarcinoma gástrico

Carcinoma mamário
$>99 \%$

$>95 \%$

$40 \%$

$5 \%$

$40 \%$

$95 \%$

$5 \%$

95\%

$>95 \%$

$20 \%$

$30 \%$

Maioria

Maioria

$40 \%$

$>95 \%$

$>95 \%$

$40 \%$

$70 \%$

$20 \%$

$<5 \%$

$50 \%$

$>95 \%$

$95 \%$

$75 \%$

Maioria

$7 \%$

0 a $51 \%$
Uma deleção característica de 30 pares de base foi identificada na extremidade 3' do gene que codifica a proteína latente, de membrana 1 (LMP1). Essa deleção foi, inicialmente, detectada em carcinomas de nasofaringe, sendo associada a maior agressividade do tumor $^{(52)}$. O LMP1 atua como um oncogene e a expressão dessa proteína, em camundongos transgênicos, resulta em linfomas de células $\mathrm{B}^{(53)}$. Isso porque o LMP1 induz um sinal que mimetiza a forma ativa da molécula de superfície CD40, nas células $\mathrm{B}^{(54)}$. O mesmo efeito não é verificado em linfócitos $\mathrm{T}$, sugerindo que o EBV promove linfomas $\mathrm{T}$ por mecanismos que não dependem do LMP $1^{(55)}$. O LMP1 se liga ao receptor do fator de necrose tumoral, tanto in vitro quanto in vivo, em linfomas positivos para EBV. Isso resulta na ativação do fator de transcrição nuclear $\mathrm{kB}(\mathrm{NF}$ $\mathrm{kB})$, na ativação do $c$ jun, na regulação de moléculas de adesão celular, na produção de citocinas e na proliferação de células B ${ }^{(56)}$. nos carcinomas mamários e nos linfomas de Burkitt, associados ao $\mathrm{EBV}^{(50)}$.

O gene do antígeno nuclear 4 do EBV (EBNA4) está frequientemente mutado na doença de Hodgkin, no carcinoma gástrico e em linfomas associados ao EBV, sugerindo que possa ter algum papel na etiopatogenia dessas neoplasias ${ }^{(51)}$.
Durante o processo de transformação neoplásica, o LMP1 ativa os receptores do fator de necrose tumoral, com ativação dos genes NF- $\gamma \mathrm{B}, \mathrm{AP}-1 \mathrm{E}$ JAK3/STAT. Isso leva à proliferação de linfócitos com supressão da capacidade de formar centros germinativos, formando linfomas ${ }^{(57)}$. A proteína LMP-1 é importante para a transformação neoplásica, podendo ser detec- 

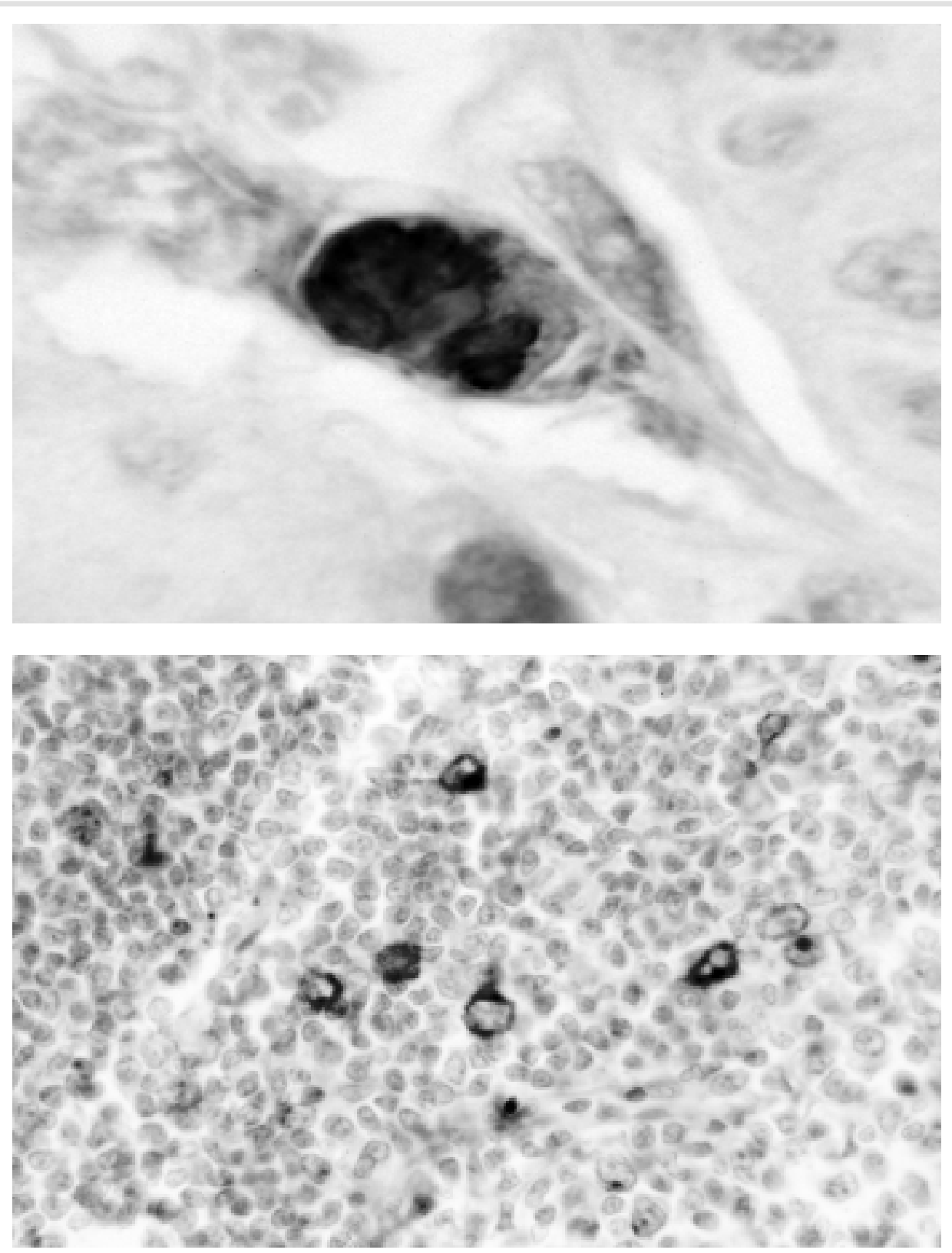

Figura 1: A) Célula neoplásica positiva para EBV EBNA-1 (carcinoma mamário). Note que o EBNA-1 apresenta padrão de marcação nuclear (imunoistoquímica, EBNA-1, x1000). B) Células neoplásicas positivas para EBV LMP-1 (linfoma não Hodgkin). Note que o LMP-1 é um marcador de membrana citoplasmática (imunoistoquímica, LMP-1, x200)

tada em tecidos parafinados pelo método imunoistoquímico (Figura 1B). Entretanto, o LMP-1, geralmente, não é mais expresso, quando o tumor já está muito avançado, sugerindo que não desempenha papel relevante na manutenção da neoplasia ${ }^{(58)}$.

Os dois tipos de RNA não transladados do EBV (EBER) não codificam proteínas, mas podem atuar como oncogenes, além de bloquear a apoptose ${ }^{(59)}$.

Além das proteínas de infecção latente do EBV terem atividade oncogênica direta, o DNA viral pene- tra no genoma do hospedeiro, podendo causar mutações somáticas em genes que regulam o ciclo celu$\operatorname{lar}^{(60)}$. O p53 é um gene regulador, chave, do ciclo celular e, em condições normais, impede que células com lesão no DNA sofram divisão mitótica, além de induzir apoptose. Por isso, o p53 é considerado um "gene supressor tumoral". Quando mutado, o gene perde sua ação regulatória, favorecendo o desenvolvimento de neoplasias malignas ${ }^{(61)}$. Mutações no p53 foram detectadas no linfoma de Burkitt e nos carcino- 
mas gástrico e de cabeça e pescoço, associados ao EBV, mas não no linfoma B de pacientes imunodeprimidos $^{(62,63)}$. Além disso, o carcinoma da nasofaringe, que é a neoplasia mais fortemente associada ao EBV, raramente apresenta mutações no p53 ${ }^{(64)}$. Esses dados sugerem que o vírus Epstein-Barr pode ter vários mecanismos de ação, cuja importância varia conforme o tecido alvo. Sob esse raciocínio, um desses mecanismos seria induzir mutação no p53, importante no linfoma de Burkitt e nos carcinomas gástrico e de cabeça e pescoço, mas não no carcinoma de nasofaringe.

\section{5- CONCLUSÃO}

Existe forte associação entre a infecção latente pelo vírus Epstein-Barr e o desenvolvimento de tumores malignos em humanos. Várias das proteínas expressas pelo EBV atuam diretamente como oncogene, estimulando a proliferação das células infectadas. Além disso, o DNA viral, ao integrar-se ao genoma do hospedeiro, pode causar mutações em genes reguladores do ciclo celular, sobretudo no gene supressor, tumoral, p53, favorecendo o aparecimento de células neoplásicas.

RIBEIRO-SILVA A \& ZUCOLOTOS. The role of Epstein-Barr virus in human tumorigenesis. Medicina, Ribeirão Preto, 36: 16-23, jan./march, 2003.

ABSTRACT: The Epstein-Barr virus, also known simply as EBV, is a virus of Herpes family that causes the infectious mononucleosis in humans. There is strong relationship between the latent infection by EBV and the development of several malignant tumors like Burkitt's lymphoma, Hodgkin disease, lymphoma of B cells and nasopharyngeal carcinoma. There are also evidences that the EBV might be associated to others malignant neoplasms mainly gastric carcinomas, mammary carcinomas, leiomyosarcomas, lymphomas of B cells and "lymphoepithelioma-like" carcinomas of salivary glands, lung and thymus. Many of the proteins expressed by the EBV act directly as a oncogene, stimulating the proliferation of the infected cells. Besides, the viral DNA, when integrated to host genome, may cause mutations in regulatory genes of cell cycle, over all the tumor suppressor gene p53, favoring the emergence of neoplastic cells.

UNITERMS: Infection. Herpesvirus 4, Human. Neoplasms.

\section{REFERÊNCIAS BIBLIOGRÁFICAS}

1 - EPSTEIN MA; ACHONG BG \& BARR YM. Virus particles in cultured lymphoblasts from Burkitt's lymphoma. Lancet 1: 702-703, 1964.

2 - HENLE G; HENLE W \& DIEHL V. Relation of Burkitt's tumorassociated herpes-type virus to infectious mononucleosis. Proc Natl Acad Sci USA 59: 94-101, 1968.

3 - BAUMFORTH KR; YOUNG LS; FLAVELL KJ; CONSTANDINOU $C$ \& MURRAY PG. The Epstein-Barr virus and its association with human cancers. J Clin Pathol: Mol Pathol 52: 307322, 1999.

4 - CRAWFORD DH. Biology and disease associations of Epstein-Barr virus. Philos Trans R Soc Lond B Biol Sci 356: 461-473, 2001.

5 - EVANS AS. Clinical syndromes associated with EB virus infection. Ann Intern Med 18: 77-93, 1972.

6 - YAO QY; RICKINSON AB \& EPSTEIN MA. A re-examination of the Epstein-Barr virus carrier state in healthy seropositive individuals. Int J Cancer 35: 35-42, 1985.
7 - ALLDAY MJ \& CRAWFORD DH. Role of epithelium in EBV persistence and pathogenesis of B-cell tumours. Lancet 1 : 855-857, 1988.

8 - NIEDOBITEK G; AGATHANGGELOU A; HERBST H; WHITEHEAD L; WRIGHT DH \& YOUNG LS. Epstein-Barr virus (EBV) infection in infectious mononucleosis: virus latency, replication and phenotype of EBV-infected cells. J Pathol 182: 151-159, 1997.

9 - SIXBEY JW; VESTERINEN EH; NEDRUD JG; RAAB-TRAUB $\mathrm{N}$; WALTON LA \& PAGANO JS. Replication of EpsteinBarr virus in human epithelial cells infected in vitro. Nature 306: 480-483, 1983.

10 - LI Q; SPRIGGS MK; KOVATS S; TURK SM; COMEAU MR; NEPOM B \& HUTT-FLETCHER LM. Epstein-Barr virus uses HLA class II as a cofactor for infection of B lymphocytes. J Virol 71: 4657-4662, 1997.

11 - FAULKNER GC; BURROWS SR; KHANNA R; MOSS DJ; BIRD AG \& CRAWFORD DH. X-linked agammaglobulinemia patients are not infected with Epstein-Barr virus: implications for the biology of the virus. J Virol 73: 15551564, 1999. 
12 - BABCOCK GJ; DECKER LL; VOLK M \& THORLEY-LAWSON DA. EBV persistence in memory B cells in vivo. Immunity 9: 395-404, 1998.

13 - COHEN Jl. Epstein-Barr virus infection. N Engl J Med 343: 481-492, 2000.

14 - YATES J; WARREN N; REISMAN D \& SUGDEN B. A cisacting element from the Epstein-Barr viral genome that permits stable replication of recombinant plasmids in latently infected cells. Proc Natl Acad Sci USA 81: 3806-3810, 1984.

15 - LEIGHT ER \& SUGDEN B. EBNA-1: a protein pivotal to latent infection by Epstein-Barr virus. Rev Med Virol 10: 83-100, 2000.

16 - YOUNG LS; DAWSON CW \& ELIOPOULOS AG. The expression and function of Epstein-Barr virus encoded latent genes. J Clin Pathol: Mol Pathol 53: 238-247, 2000.

17 - MURRAY PG; LISSAUER D; JUNYING J; DAVIES G; MOORE S; BELL A; TIMMS J; ROWLANDS D; MCCONKEY C; REYNOLDS GM; GHATAURA S; ENGLAND D; CAROLL R \& YOUNG LS. Reactivity with A monoclonal antibody to Epstein-Barr virus (EBV) nuclear antigen 1 defines a subset of aggressive breast cancers in the absence of the EBV genome. Cancer Res 63: 2338-2343, 2003.

18 - JOHANNSEN E; KOH E; MOSIALOS G; TONG X; KIEFF E \& GROSSMAN SR. Epstein-Barr virus nuclear protein 2 transactivation of the latent membrane protein 1 promoter is mediated by J kappa and PU1. J Virol 69: 253-262, 1995.

19 - LIN J; JOHANNSEN E; ROBERTSON E \& KIEFF E. EpsteinBarr virus nuclear antigen $3 c$ putative repression domain mediates coactivation of the LMP1 promoter with EBNA2. J Virol 76: 232-242, 2002.

20 - MILLER CL; BURKHARDT AL; LEE JH; STEALEY B; LONGNECKER R; BOLEN JB \& KIEFF E. Integral membrane protein 2 of Epstein-Barr virus regulates reactivation from latency through dominant negative effects on protein-tyrosine kinases. Immunity 2: 155-166, 1995.

21 - CALDWELL RG; WILSON JB; ANDERSON SJ \& LONGNECKER R. Epstein-Barr virus LMP2A drives B cell development and survival in the absence of normal B cell receptor signals. Immunity 9: 405-411, 1998.

22 - SAMPLE J; YOUNG L; MARTIN B; CHATMAN T; KIEFF E; RICKINSON A \& KIEFF E. Epstein-Barr virus types 1 and 2 differ in the EBNA-3a, EBNA-3b and EBNA-3c genes. J Virol 64: 4084-4092, 1990.

23 - RICKINSON AB; YOUNG LS \& ROWE M. Influence of Epstein-Barr virus nuclear antigen EBNA-2 on the growth phenotype of virus-transformed B cells. J Virol 61: 13101317, 1987.

24 - SHIBATA D; WEISS LM; HERNANDEZ AM; NATHWANI BN; BERNSTEIN L \& LEVINE AM. Epstein-Barr virus-associated non-Hodgkin's lymphoma in patients infected with human immunodeficiency virus. Blood 81: 2102-2109, 1993.

25 - CHEN WG; CHEN YY; BACCHI MM; BACCHI CE; ALVARENGA $M$ \& WEISS LM. Genotyping of Epstein-Barr virus in Brazilian Burkitt's lymphoma and reactive lymphoid tissue. Type $A$ with a high prevalence of deletions within the latent membrane protein gene. Am J Pathol 148: 17-23, 1996.

26 - ZUR HAUSEN H; SCHULTE-HOLTHAUSEN H; KLEIN G; HENLE W; HENLE G; CLIFFORD P \& SANTESSON L. EBV DNA in biopsies of Burkitt's tumours and anaplastic carcinomas of the nasopharynx. Nature 228: 1056-1058, 1970.
27 - ZIEGLER JL; DREW WL; MINER RC; MINTZ L; ROSENBAUM E; GERSHOW J; LENNETTE ET; GREENSPAN J; SHILLITOE E; BECKSTEAD J; CASAVANT C \& YAMAMOTO K. Outbreak of Burkitt's-like lymphoma in homosexual men. Lancet 2: 631-633, 1982.

28 - GREENSPAN JS; GREENSPAN D; LENNETTE ET; ABRAMS DI; CONANT MA; PETERSEN V \& FREESE UK. Replication of Epstein-Barr virus within the epithelial cells of oral "hairy leukoplakia, an AIDS-associated lesion. N Engl J Med 313: 1564-1571, 1985.

29 - JONES JF; SHURIN S; ABRAMOWSKY C; TUBBS RR; SCIOTTO CG; WAHL R; SANDS J; GOTTMAN D; KATZ BZ \& SKLAR J. T-cell lymphomas containing Epstein-Barr viral DNA in patients with chronic Epstein-Barr virus infections. N Engl J Med 318: 733-741, 1988.

30 - WEISS LM; MOVAHED LA; WARNKE RA \& SKLAR J. Detection of Epstein-Barr viral genomes in Reed-Sternberg cells of Hodgkin's disease. N Engl J Med 320: 502-506, 1989.

31 - NIEDOBITEK G. The Epstein-Barr virus: a group 1 carcinogen? Virch Arch 435: 79-86, 1999.

32 - VORTMEYER AO; KINGMA DW; FENTON RG; CURTI BD; JAFFE ES \& DURAY PH. Hepatobiliary lymphoepitheliomalike carcinoma associated with Epstein-Barr virus. Am J Clin Pathol 109: 90-95, 1998.

33 - BONNET M; GUINEBRETIERE JM; KREMMER E; GRUNEWALD $V$ \& BENHAMOU E; CONTESSO G; JOAB I. Detection of Epstein-Barr virus in invasive breast cancers. J Natl Cancer Inst 91: 1376-1381, 1999.

34 - JENG Y-M; CHEN C-L \& HSU H-C. Lymphoepithelioma-like cholangiocarcinoma: an Epstein-Barr virus-associated tumor. Am J Surg Pathol 25: 516-520, 2001.

35 - KIJIMA Y; HOKITA S; TAKAO S; BABA M; NATSUGOE S; YOSHINAKA H; ARIDOME K; OTSUJI T; ITOH T; TOKUNAGA $M$; EIZURU Y \& AIKOU T. Epstein-Barr virus involvement is mainly restricted to lymphoepithelial type of gastric carcinoma among various epithelial neoplasms. J Med Virol 64: 513-518, 2001.

36 - HOSHIKAWA Y; SATOH Y; MURAKAMI M; MAETA M; KAIBARA N; ITO H; KURATA T \& SAIRENJI T. Evidence of lytic infection of Epstein-Barr virus (EBV) in EBV-positive gastric carcinoma. J Med Virol 66: 351-359, 2002.

37 - KANG GH; LEE S; KIM WH; LEE HW; KIM JC; RHYU MG \& RO JY. Epstein-Barr virus-positive gastric carcinoma demonstrates frequent aberrant methylation of multiple genes and constitutes $\mathrm{CpG}$ island methylator phenotype-positive gastric carcinoma. Am J Pathol 160: 787-794, 2002.

38 - CHEN PC; PAN CC; HSU WH; KA HJ \& YANG AH. EpsteinBarr virus-associated lymphoepithelioma-like carcinoma of the esophagus. Hum Pathol 34: 407-411, 2003.

39 - HERRMANN K \& NIEDOBITEK G. Epstein-Barr virus-associated carcinomas: facts and fiction. J Pathol 199: 140-145, 2003.

40 - CASTRO CY; OSTROWSKI ML; BARRIOS R; GREEN LK; POPPER HH; POWELL S; CAGLE PT \& RO JY. Relationship between Epstein-Barr virus and lymphoepithelioma-like carcinoma of the lung: a clinicopathologic study of 6 cases and review of the literature. Hum Pathol 32: 863-872, 2001.

41 - PEH S-C. Host ethnicity influences non-Hodgkin's lymphoma subtype frequency and Epstein-Barr virus association rate: the experience of a multi-ethnic patient population in Malaysia. Histopathology 38: 458-465, 2001. 
42 - KORIYAMA C; AKIBA S; IRIYA K; YAMAGUTI T; HAMADA GS; ITOH T; EIZURU Y; AIKOU T; WATANABE S; TSUGANE S \& TOKUNAGA M. Epstein-Barr virus associated gastric carcinoma in Japanese Brazilians and non-Japanese Brazilians in São Paulo. Jpn J Cancer Res 92: 911-917, 2001.

43 - GULLEY ML. Molecular diagnosis of Epstein-Barr virusrelated diseases. J Mol Diagn 3: 1-10, 2001.

44 - KNECHT H; BERGER C; ROTHENBERGER S; ODERMATT BF \& BROUSSET P. The role of Epstein-Barr virus in neoplastic transformation. Oncology 60: 289-302, 2001.

45 - KRAUS RJ; MIROCHA SJ; STEPHANY HM; PUCHALSKI JR \& MERTZ JE. Identification of a novel element involved in regulation of the lytic switch BZLF1 gene promoter of EpsteinBarr virus. J Virol 75: 867-877, 2001.

46 - WILSON JB; BELL JL \& LEVINE AJ. Expression of EpsteinBarr virus nuclear antigen-1 induces B cell neoplasia in transgenic mice. EMBO J 15: 3117-3126, 1996.

47 - OUDEJANS JJ; DUKERS DF; JIWA NM; VAN DEN BRULE AJ; GRASSER FA; DE BRUIN PC; HORSTMAN A; VOS W; VAN GORP J; MIDDELDORP JM \& MEIJER CJ. Expression of Epstein-Barr virus encoded nuclear antigen 1 in benign and malignant tissues harbouring EBV. J Clin Pathol 49: 897902, 1996.

48 - FUJIWARA S. Epstein-Barr virus nuclear protein 2-induced activation of the EBV-replicative cycle in Akata cells: analysis by tetracycline-regulated expression. Curr Top Microbiol Immunol 258: 35-50, 2001.

49 - SUBRAMANIAN C; KNIGHT JS \& ROBERTSON ES. The Epstein-Barr nuclear antigen EBNA3c regulates transcription, cell transformation and cell migration. Front Biosci 7: 704716,2002

50 - SUBRAMANIAN C; COTTER MA \& ROBERTSON ES. EpsteinBarr virus nuclear protein EBNA-3C interacts with the human metastatic suppressor Nm23-H1: a molecular link to cancer metastasis. Nat Med 7: 350-355, 2001.

51 - CHU PG; CHANG KL; CHEN WG; CHEN YY; SHIBATA D; HAYASHI K; BACCHI C; BACCHI M \& WEISS LM. EpsteinBarr virus (EBV) nuclear antigen (EBNA)-4 mutation in EBVassociated malignancies in three different populations. Am J Pathol 155: 941-947, 1999.

52 - CHEN ML; TSAI CN; LIANG CL; SHU CH; HUANG CR; SULITZEANU D; LIU ST \& CHANG YS. Cloning and characterization of the latent membrane protein (LMP) of a specific Epstein-Barr virus variant derived from nasopharyngeal carcinoma in the Taiwanese population. Oncogene 7: 2131-2140, 1992.

53 - KULWICHIT W; EDWARDS RH; DAVENPORT EM; BASKAR JF; GODFREY V \& RAAB-TRAUB N. Expression of the Epstein-Barr virus latent membrane protein 1 induces $B$ cell lymphoma in transgenic mice. Proc Natl Acad Sci USA 95: 11963-11968, 1998.
54 - UCHIDA J; YASUI T; TAKAOKA-SHICHIJO Y; MURAOKA M; KULWICHIT W; RAAB-TRAUB N \& KIKUTANI $\mathrm{H}$. Mimicry of CD40 signals by Epstein-Barr virus LMP1 in B lymphocyte responses. Science 286: 300-303, 1999.

55 - XU J; AHMAD A \& MENEZES J. Preferential localization of the Epstein-Barr virus (EBV) oncoprotein LMP-1 to nuclei in human T cells: implications for its role in the development of EBV genome-positive T-cell lymphomas. J Virol 76: 40804086, 2002.

56 - LIEBOWITZ D. Epstein-Barr virus and a cellular signaling pathway in lymphomas from immunosuppressed patients. $\mathbf{N}$ Engl J Med 338: 1413-1421, 1998.

57 - KNECHT H; BERGER C; ROTHENBERGER S; ODERMATT BF \& BROUSSET P. The role of Epstein-Barr virus in neoplastic transformation. Oncology 60: 289-302, 2001.

58 - OHSHIMA K; SUZUMIYA J; KANDA M; HARAOKA S; KAWASAKI C; SHIMAZAKI K \& KIKUCHI M. Genotypic and phenotypic alterations in Epstein-Barr virus-associated lymphoma. Histopathology 35: 539-550, 1999.

59 - KOMANO J; MARUO S; KUROZUMI K; ODA T \& TAKADA K. Oncogenic role of Epstein-Barr virus-encoded RNAs in Burkitt's lymphoma cell line Akata. J Virol 73: 9827-9831, 1999.

60 - HAUSEN HZ. Oncogenic DNA viruses. Oncogene 20: 7820-7823, 2001.

61 - HOLLSTEIN M; SIDRANSKY D; VOGELSTEIN B \& HARRIS CC P53 mutations in human cancers. Science 253: 49, 1991.

62 - CHAN WY; CHAN EKL \& CHOW JHS. Epstein-Barr virusassociated gastric lymphomas are distinct from mucosaassociated lymphoid tissue-type lymphomas: genetic abnormalities of p53 gene. Diagn Mol Pathol 10: 153-160, 2001.

63 - YANG HJ; CHO YJ; KIM HS; CHANG MS; SUNG MW \& KIM WH. Association of p53 and BCL-2 expression with EpsteinBarr virus infection in the cancers of head and neck. Head Neck 23: 629-636, 2001.

64 - CROOK T; NICHOLLS JM; BROOKS L; O'NIONS J \& ALLDAY MJ. High level expression of deltaN-p63: a mechanism for the inactivation of p53 in undifferentiated nasopharyngeal carcinoma (NPC)? Oncogene 19: 3439-3444, 2000.

Recebido para publicação em 26/12/2002

Aprovado para publicação em 31/03/2003 